\title{
Awareness towards Accountancy as a Profession
}

\author{
Azrinawati Mohd Remali ${ }^{1}$, Kirrthini Apalasamy ${ }^{2}$, Logalatha Jegadeesvaran ${ }^{3}$, Mahasri Laxmanarao ${ }^{4}$ \\ \& Rogany Morgan ${ }^{5}$ \\ 1,2,3,4,5 Universiti Tenaga Nasional, Malaysia
}

\begin{tabular}{|c|c|}
\hline ARTICLE INFO & \multirow{11}{*}{$\begin{array}{l}\text { ABSTRACT } \\
\text { This study investigates the awareness of secondary school students } \\
\text { towards accountancy as a profession due to the shortage of qualified } \\
\text { accountants required by Malaysia government in the era } 2020 \text {. A lack } \\
\text { of information/misinformation about what accounting is and what } \\
\text { accountants do which caused the school leavers having less awareness } \\
\text { regarding the accountancy profession. There are four factors that been } \\
\text { tested; namely as gender, personal interest, level of difficulties for } \\
\text { accounting subject as well as knowledge and career prospects. The } \\
\text { study focuses on secondary school students and } 270 \text { students who } \\
\text { taking Principle of Account subject at Segamat, Johor and Muadzam } \\
\text { Shah, Pahang secondary. The analysis of data utilizes the statistical } \\
\text { package of SPSS. The result revealed that personal interests as well as } \\
\text { knowledge and career prospects have significant relationship with the } \\
\text { awareness of students towards accountancy as a profession. } \\
\text { Meanwhile gender and level of difficulties for accounting subject do } \\
\text { not have significance difference/relationship with the awareness of } \\
\text { students towards accountancy as a profession. }\end{array}$} \\
\hline Article history: & \\
\hline Received: April 20, 2019 & \\
\hline 2019 & \\
\hline Accepted: & \\
\hline Keywords: & \\
\hline Accountancy, & \\
\hline Awareness, & \\
\hline Secondary School Students & \\
\hline Clonflict of Interest: & \\
\hline None & \\
\hline
\end{tabular}

Funding:

None

Corresponding Author: Azrinawati Mohd Remali, Email: azrinawati@uniten.edu.my

(C) A. Remali, K. Apalasamy, L. Jegadeesvaran, M. Laxmanarao \& R. Morgan

This is an open access article under the CC BY-SA 4.0 international license.

\section{Introduction}

Malaysia need around 60,000 qualified accountants by the year 2020, but currently Malaysia facing with the shortage by more than half of the number (The Star Online, 2010). There are currently about 30,000 accountancy professionals in Malaysia, of which $28 \%$ are registered chartered accountants. Malaysia needs to double its accountants to 60,000 in an effort to support its transformation into a developed nation (New Straits Times, 2015). According to an article in Utusan Malaysia (2015), Datuk Seri Abdul Wahid Omar from Prime Minister's Office revealed that only eight percent from 32,000 professional accountants are Bumiputera and the reason for this issue occurred because of low exposure levels in accounting field requires high knowledge in managing numbers and having a good fluency English. In addition, Samsuri et al. (2016), mentioned in their study that in Malaysia recently when the country needs more accountants to assist the country to achieve the nation of 'Wawasan 2020' however not many qualified people are establishing in the fields and it may give a sign that a few determinants may affect the students to continue on this areas.

Hence, this study tend to investigate the awareness of secondary school students towards accountancy as a profession which focusing the students who taking Principle of Account subject at Muadzam Shah, Pahang and Segamat, Johor secondary schools are selected as sample. The objectives of this research are:

(1) To determine student's level of awareness towards accountancy as a profession and

(2) To identify factors (gender, personal interest, level of difficulties and knowledge and career prospects) that will give impact to the awareness of students towards accountancy as a profession.

\subsection{Problem Statement}

There are several reasons for students not majoring in accounting, for instance accountant's starting salaries are lower than for other business majors and it is due to lack of experience and skills in working environment hence they are fresh graduates. Besides that, students today have more attractive career alternatives than in the past. Those days although it is a difficult profession, there is a must to work in that accounting firm. But 
nowadays students prefer to take easiest course as their wish. For example many students prefer to take International Business, Human Resources and others which are easier than accounting course (Questia Trusted Online Research, 2016)

Questia Trusted Online Research (2016), also found that there was a lack of information and considerable misinformation about what accounting is and what accountants do. The SPM and STPM leavers are having less exposure regarding the accounting course. It is may be due to some schools reluctant to provide education fair and lack of extra knowledge from profession people, people who are not interested, may give misinformation and underestimate that course.

Thus, this research tend to contribute to the Wawasan 2020 mentioned by Datuk Seri Abdul Wahid Omar in Astro Awani, (2015) by achieving the transformation to a developed nation by 2020, Malaysia needs to double the number of accountants to 60,000 because now there are about 30,000 professional accountants in Malaysia. It will be very helpful to everyone in future who has an idea or ambition to join in accounting field.

\section{Literature Review}

\subsection{Gender}

Law and Desmond (2012) found that female students are more likely to choose an accounting major or minor compared than males. The percentage of male students can be increase by choosing accounting as a major by providing more seminars, workshops, and career fairs to attract male students to study accounting. Besides that, university staff could also conduct more briefings at schools about colleges in order to encourage male students whether to decide in choosing major or minor in accounting. Nelson and Vendryzk (1996) cited by Law and Desmond (2012) found that male students showing a less favorable attitude toward accounting than their female counterparts. In addition, Odia and Ogiedu (2013) also found that males are more likely to choose accounting than female. Factors such as parents, parent's occupation, friends, teacher's fellow students and counselor were main reasons for male students to choose accountancy than the female students.

Therefore the first hypothesis is constructed to be tested:

$H_{1}$ : There is a significant difference between gender and student's awareness towards accountancy as a profession.

\subsection{Personal interest}

Research done by Azmi (2004) on students interest in studying accounting subject revealed that the majority of students with 35.74 percent are interested in studying accounting subject while 31.3 percent of MRSM students are 'very interested' and only 28.51 percent students are strongly interested. Odia and Ogiedu (2013) found that personal and job factors such as students' interest and motivation in the subject and it tells that personal factors have a very high influence on student's choice of accounting about 85 percent. It was also discovered that personal factors and job-related factors such as student interest, prospects of high paying job and performance in secondary school had stronger influence on the choice of accounting by universities' undergraduate in Nigeria. Manganaris and Spathis (2015) revealed that 35.1 percent are intends to attend additional accounting courses whereas 64.9 percent students denied. From this survey, it gave a negative impact on awareness of students towards accountancy as a profession. But among those respondents who choose additional accounting course are interested in accounting had more positive initial perceptions of the course than those who were not interested.

As a result, the second hypothesis is posted:

$\mathrm{H}_{2}$ : There is a significant relationship between personal interest and student's awareness towards accountancy as a profession.

\subsection{Level of difficulties for accounting subject}

Simon et al. (1997) implied that to become a Chartered of Profession Accountant (CPA) it required 150 hours which is less than other field such as law, medicine and engineer. In other hand, it increases the level of difficulties to the students because there is limited time to study to become a CPA. It might reduce students interest when there is limited hours to study CPA. Azmi (2004) had done a survey on MRSM student's opinion towards level of difficulties. It concluded that most of MRSM students agreed that accounting subject is a moderate subject where it is not so easy and not so hard.

Thus, the third hypothesis is developed as follow:

$H_{3}$ : There is a significant relationship between levels of difficulties for accounting subject and student's awareness towards accountancy as a profession. 


\subsection{Knowledge and career prospects}

Azmi (2004) found that to achieve the country's Vision 2020 the demands and expectations towards accountants will increase and need good education system and identifying good students in order to increase the quantity and quality of accountants. However, the overall findings not those satisfy because students have limited knowledge of accountant job functions. Indirectly this gives a negative impact on student's awareness of accounting as a profession. Zainal et al (2011) concluded that it is not a necessary to be a future accountant if they take accounting subject instead, they will have an opportunity to be a better entrepreneur. Meanwhile, Weli (2014) analyzed that students are studying Accounting Information System (AIS) as subject found that private universities students are unaware about the importance of computer literacy that can help them in workplace. To enhance the efficiency of students' knowledge on computers, the lecturers should provide a better model of the AIS course content in the education institution that is aligned with the workplace.

As a result, the following hypothesis is posted:

$H_{4}$ : There is a significant relationship between knowledge and career prospects and student's awareness towards accountancy as a profession.

\section{Methodology}

\subsection{Population and Sample}

The data are collected using questionnaire which are distributed to the all students who are taking Principle of Accounts subject in 2016. There are 440,682 students sitting for SPM examinations (My Sumber, 2015) in Malaysia. This research have select two areas which are Muadzam Shah and Segamat secondary schools to get samples. Convenience sampling is being use where those schools are nearby to Universiti Tenaga Nasional (UNITEN). Convenience sampling is being use as the collection of information from members of the population who are conveniently available to provide it. This sampling is often used during the explanatory phase of a research project of getting some basic information quickly and efficiently.

The questionnaire use in the study is adapted from Azmi (2004), Weli (2014) and Manganaris and Spathis (2015). There are two parts of the questionnaire. The first part of the questionnaire is solicited demographic information's such as gender, race, age and family accounting background. The second part of the questionnaire is further divided into three sections that are A (personal interest), B (level of difficulties for accounting subject), and C (knowledge and career prospects). The questions for Section A and B are measured by using a 5 point Likert scale ( $1=$ Strongly Disagree to $5=$ Strongly Agree), meanwhile for Section C using Yes or No statements.

In examining the relationship between factors influencing student's awareness towards accounting as a profession, the data collected from the questionnaire distributed will be tested using Statistical Package for Social Science version 23. The project paper used the normality test, the reliability test, the descriptive statistics and the correlation test to analyse the data.

\section{Results}

\subsection{Normality Test}

The data was analysed using the Kolmogorov-Smirnov because the population of this study was more than 100. It shows that level of significant is 0.000 which indicates that the data was not normal distributed (Coakes, Steed and Ong, 2010) and further analysis will be discussed using non-parametric analysis.

\subsection{Reliability Test}

The results for the reliability test using the Cronbach's Alpha test shows that the questionnaire was reliable with a score of 0.60. Sekaran and Bougie (2011) stated that a Cronbach Alpha within 0.5 to 0.75 is generally accepted as indicating a fairly reliability. Thus, it indicates that all of the questions are acceptable for further analysis

\subsection{Descriptive Analysis}

The questionnaire was distributed to SPM's students in selected school in Segamat, Johor and Muadzam Shah, Pahang. A total of 270 copies of questionnaire were returned back and usable for further analysis. It is able to use for further analysis. Table 4.3.1 shows the descriptive analysis from each school and as total.

Table 4.3.1: Demographic Analysis (Segamat and Muadzam Shah)

\begin{tabular}{ccccccc}
\hline & \multicolumn{2}{c}{ Segamat } & \multicolumn{2}{c}{ Muadzam Shah } & \multicolumn{2}{c}{ Total } \\
\hline & Frequency & $\%$ & Frequency & $\%$ & Frequency & $\%$ \\
\hline Gender & 64 & 40 & 40 & 36.36 & 104 & 38.5 \\
Male & 96 & 60 & 70 & 63.64 & 166 & 61.5 \\
\hline Female & & & & ASHREJ Vol. 1, No. 2, 2019: 1 - 6
\end{tabular}




\begin{tabular}{ccccccc}
\hline Race & & & & & & \\
Malay & 121 & 75.63 & 109 & 99.09 & 230 & 85.2 \\
Chinese & 27 & 16.88 & 0 & 0 & 27 & 10 \\
Indian & 12 & 7.5 & 0 & 0 & 12 & 4.4 \\
Others & 0 & 0 & 1 & 0.91 & 1 & 0.4 \\
\hline Age & & & & & & \\
16 years & 84 & 52.5 & 63 & 57.27 & 147 & 54.4 \\
17 years & 75 & 46.88 & 46 & 41.82 & 121 & 44.8 \\
18 years & 1 & 0.63 & 1 & 0.91 & 1 & 0.7 \\
19 years & 0 & 0 & 0 & 0 & 0 & 0 \\
\hline Family Background & & & & & & 33.7 \\
Accounting related & 52 & 32.5 & 39 & 35.45 & 91 & 66.3 \\
Not accounting related & 108 & 67.5 & 71 & 64.55 & 179 & 66.79 \\
\hline
\end{tabular}

4.4 Results and Findings

Table 4.4.1: Level of awareness

\begin{tabular}{llrlllc}
\hline & \multicolumn{2}{c}{ Segamat } & \multicolumn{2}{c}{ Muadzam Shah } & \multicolumn{2}{c}{ Total } \\
\hline & Frequency & $\%$ & Frequency & \multicolumn{1}{c}{$\%$} & Frequency & $\%$ \\
\hline Yes & 127 & 79.38 & 108 & 98.18 & 235 & 87.04 \\
No & 33 & 20.63 & 2 & 1.82 & 35 & 12.96 \\
\hline
\end{tabular}

Level of awareness is measured by the percentage of respondents' awareness towards accountancy as a profession. Table 4.4.1 shows that 79.38 percent are aware and only 20.63 percent are not aware from Segamat schools. In other hand, 98.18 percent from Muadzam Shah Schools are aware of accountancy as a profession and only 1.82 percent are not aware. It shows that students in Muadzam Shah have more awareness towards accountancy as a profession compared to the students in Segamat. As a conclusion, a total of 235 respondents (87.04 percent) are aware towards accountancy as profession with 35 respondents (12.96 percent) are not aware. Thus, this study indicate that majority of the students are aware towards accountancy as a profession.

Table 4.4.2: Mann-Whitney U test

\begin{tabular}{ll}
\hline & $\begin{array}{l}\text { Are you aware towards accountancy } \\
\text { as a profession? }\end{array}$ \\
\hline Mann-Whitney U & 8022.000 \\
\hline $\mathrm{Z}$ & -1.679 \\
\hline Asymp. Sig. (2-tailed) & .093 \\
\hline a. Grouping Variable: gender
\end{tabular}

The first hypothesis $\left(\mathrm{H}_{1}\right)$ is to study whether there is a significant difference between gender and students awareness towards accountancy as a profession. The hypothesis was tested using the Mann-Whitney U-test as there were only two independent samples come from the population of gender which were male and female. Refer to Table 4.4.2, the results shows that $\mathrm{Z}=-1.679, \mathrm{p}>0.05$, and therefore, no significant difference between male and female. Both genders give no effect to the student's awareness towards accountancy as a profession. Thus, the $\mathrm{H}_{1}$ was not supported.

This result is in contrast with Odia, and Ogiedu (2013) where it stated that males are more likely to choose accounting than female because factors such as parents, parent's occupation, friends, teachers, fellow students and counselor were main reasons for male students to choose accountancy than the female students. Law and Desmond (2012) also do not support the result whereby female students are more likely to choose an accounting major or minor compared than males.

Table 4.4.3: Spearman Test (correlations)

\begin{tabular}{lll}
\hline & $\begin{array}{l}\text { Awareness } \\
\text { accountancy as a profession }\end{array}$ & Sig. (2-tailed) \\
\hline Personal interest $\left(\mathrm{H}_{2}\right)$ & $-0.326^{* *}$ & 0.000 \\
\hline Level of difficulties for accounting subject $\left(\mathrm{H}_{3}\right)$ & -0.092 & 0.132 \\
\hline Knowledge and career prospects $\left(\mathrm{H}_{4}\right)$ & $0.211^{*}$ & 0.000 \\
\hline
\end{tabular}


Based on the Table 4.4.3, the result shows that personal interest $\left(\mathrm{H}_{2}\right)$ and Knowledge and career prospects $\left(\mathrm{H}_{4}\right)$ was statistically significant towards accountancy as a profession, $\mathrm{p}<0.01)$. Therefore, the hypothesis for $\mathrm{H}_{2}$ and $\mathrm{H}_{4}$ will be supported. For $\mathrm{H}_{2}$, the result indicates negative way (if the student's personal interest is high, the level of awareness is low). It means for the students awareness towards accountancy as a profession do not need to have personal interest. This result is supported by Azmi (2004), but contradict with Odia and Ogiedu (2013). Meanwhile for $\mathrm{H}_{4}$, the result is supported by Zainal et.al. (2011) and Weli (2014) which agreed that the knowledge and career prospects are associated with awareness towards accountancy as a profession.

In contrary, there is no significant relationship between levels of difficulties for accounting subject $\left(\mathrm{H}_{3}\right)$ with student's awareness towards accountancy as a profession. Thus, $\mathrm{H}_{3}$ was not supported. The result is supported by Simons et al. (1997) and Azmi (2004) which also found that level of difficulties for accounting subject not associated with awareness towards accountancy as a profession.

\section{Conclusion}

The questionnaire's variables were distributed into four part which are gender, personal interest, level of difficulties and knowledge and career prospects. This study has found that students from Muadzam Shah, Pahang schools and Segamat, Johor schools have a positive feedback on the awareness of accountancy as profession. In addition, this study revealed that gender and level of difficulties do not have any significant difference/relationship towards accountancy as a profession whereas, factor of personal interest has been negatively significant relationship while knowledge and career prospect are positively significant relationship with the awareness of students towards accountancy as a profession.

\section{Limitation}

The finding of the study has a significant limitation comes from small population size will lead to difficulty in generalized the results based on larger populations. This is because the targeted respondents focus only in Muadzam Shah, Pahang and Segamat, Johor schools.

Besides that, the Likert scales also affect the result of the study since respondents might answer the questions with neutral range of scale (Joshi et.al. 2003). For example, based on this study, most of the respondents answered neutral range of scale by choosing "neutral". It may because they do not understand the questions. By this it is hard for the researcher to identify whether the students are agreed or not agreed with the statement. Gathering data through questionnaires to analyse might not provide the full information of date compare to face to face interviews (Watty, 2005). Respondents tend to leave the questions if they do not understand it if it was questionnaires differs from interviews that the interviewer can explain more details which will lead to the richness of data collected.

Other limitation students are also not aware on their knowledge and career prospects. They do not know much about professional accounting bodies such as ACCA, CPA and others. According to Wells and Fieger (2006), due to the lack of information about the nature of accounting and the duties performed by accountants, there is a fall in enrolment in accounting programs in United States of America.

\section{Recommedation}

Further research may consider expanding the data collection throughout Malaysia. Therefore, it could generalize the finding by increasing his or her total respondent to get more accurate answer that will represent all students all over the country.

Interviews would be more advantages compare to questionnaires since it can clarify the questions that are doubt by the respondents. Sekaran and Bougie (2011) stated that other than questionnaires, personal or face-to-face interviews could be implementing in the research. Other than that, the richness of data could be collected from the interviews since the respondents provide the information which helps the interviewer to understand the complex issues, providing ideas that is difficult to convey through questionnaire.

To increase the number of accountant, further programs can be organized by the professional accounting bodies such as ACCA and CPA in offering relevant courses, seminars and campaigns to attract more accounting students who are of higher concern on job security and job opportunity. Benefits of having professional certificates are to enhance the student's knowledge, skills and abilities to fit the changes in development of accounting profession. Therefore, the professional accounting bodies should create the relevant events to enhance the awareness of students and inform students of ways the professional certificates can be used to manage one's career and remain marketable in workplace.

Lastly, recommended by university's accounting educators must utilize teaching methods that foster student self-efficacy and establish a belief that the student can further proceed on this area when the students are continuing their higher education. By this, the students will have positive influence and feel motivate in order to pursue their career as a professional accountant. Furthermore, the university's accounting educators should provide a robust accounting programme and curriculum mainly in practically-oriented and training to create 
more interest to students to encourage students to pursue professional accountant after completing their undergraduate accounting degree as discussed by Samsuri et al. (2016).

\section{References}

Astro Awani (2015). Malaysia perlukan 60,000 akauntan menjelang 2020. Retrieved from http://www.astroawani.com/berita-bisnes/malaysia-perlukan-60-000 - Akauntan-menjelang-202060752

Azmi, N. A. (2004). Student's awareness towards accountancy as a profession. National Research Journal, 2(1), 43-54.

Coakes, S.J., \& Steed, L. \& Ong, C. (2010). SPSS: Analysis without Anguish. Version 17 for windows. Australia.John Wiley \& Sons Australia, Ltd.

Coakes, S.J., \& Steed, L. \& Ong, C. (2010). SPSS: Analysis without Anguish. Version 17 for windows. Australia.John Wiley \& Sons Australia, Ltd.

Law, P \& Desmond, Y. (2012). A multilevel study of students' motivations of studying accounting. Education + Training, 54(1), 50 - 64.

Joshi, P.L. Al-Mudhaki, J. \& Bremser, G. (2003). Corporate budget planning, control and performance evaluation in Bahrain.Managerial Auditing Journal, 18(9), 737 -750.

Manganaris, P. \& Spathis, C. (2015). Greek students' perceptions of an introductory accounting course and the accounting profession. Advances in Accounting Education: Teaching and Curriculum Innovations, 13(1), 59-85.

My Sumber. (2015). Jumlah keseluruhan calon dapat A SPM 2015, Retrieved from: http://www.mysumber.com/jumlah-keseluruhan-calon-dapat-a-spm-2015.html

Nelson, T. and Vendryzk, V. (1996), Trends in accounting student characteristics. Journal of Accounting Education, 14(4), 453-75.

New Strait Times. (2015). Malaysia needs 60,000 accountants by 2020. Retrieved from http://www.nst.com.my/news/2015/09/malaysia-needs-60000-accountants-2020

Odia, J.O. \& Ogiedu, K.O. (2013). Factors Affecting the Study of Accounting in Nigerian Universities. Journal of Educational and Social Research MCSER Publishing, Rome-Italy, 3 (3), 89-96.

Questia Trusted Online Research (2016). Students majoring in accounting. Retrieved from, https://www.questia.com/library/journal/1P3-549132321/why-dont-Students-major-in-accounting

Samsuri A.S., Arifin T.R. \& Hussin S. (2016). Perception of Undergraduate Accounting Students towards Professional Accounting Career. Journal of Academic Research in Accounting, Finance and Management Sciences, 6(3),78-88.

Simon, K. A. Lowe, D.R. \& Stout, D.E. (1997). Factors Influencing Choice of Accounting as a Major. Brayant College.

Sekaran. U. \& Bougie, R. (2011). Research Method for Business: A Skill Building $\quad$ Approach. $\quad 6^{\text {th }}$ Edtion. Canada: John Wiley \& Sons. Inc.

The Star Online. (2010). Making professional accounting cool. Retrieved from http://www.thestar.com.my/business/business-news/2015/03/06/

Wells, P. \& Fieger, P. (2006). High school teachers' perceptions of accounting: an international study. Australian Journal of Accounting Education, 2 (1) 30-51.

Weli. (2014). Accounting students attitude towards computer, the acceptance of the accounting information system's course and teaching method. Procedia - Social and Behavioral Sciences, 172 (1) 18 - 25

Watty, K. (2005). Quality in accounting education. Quality Assurance in Education, 13(2), 120 - IPEDR, 20(1), 141-143.

Zainal, I. Suhaida, A. K. \& Zaidatol, A. L. P. (2011). Career Aspiration amon Secondary School Accounting Students in Selangor. International Conference on Humanities, Society and Culture IPEDR, 20(1), 141-143. 